\title{
Characteristics of local groundwater recharge cycles in South African semi-arid hard rock terrains - rainwater input
}

\author{
E van Wyk ${ }^{1 *}$, GJ van Tonder ${ }^{2}$ and D Vermeulen ${ }^{2}$ \\ ${ }^{1}$ Hydrological Services, Department of Water Affairs, Private Bag X313, Pretoria, South Africa \\ ${ }^{2}$ Institute for Groundwater Studies, University of the Free State, P.O. Box 339, Bloemfontein, South Africa
}

\begin{abstract}
Rainfall events in semi-arid regions of South Africa are characteristically erratic in terms of depths and recurrence rates. Chemical assessment of cyclic rainwater has recognised 3 intervals, spaced over the hydrological cycle, reporting diverse hydrochemical compositions of rainwater in winter and summer rainfall regions. Winter rainwater is generated over the south Atlantic maritime waters. This rainwater contains noticeably higher concentrations of oceanic aerosols $(\mathrm{NaCl})$ than the summer rainwater generated in the Intertropical Convergence Zone/equatorial western Indian Ocean. Sporadic addition of terrigenous dust generated over the continent substantially elevates concentrations of non-oceanic nitrogenous and sulphurous aerosols in the summer rainwater. Prominent seasonal variations in the rainwater hydrochemistry signature coincide with cyclic rainfall depths, characteristic of the semi-arid climate. Macro-element concentrations during the summer dry period, April to September, are relatively high in relation to those recorded for the wet cycle, October to March. However, the latter period reports a noticeably depleted hydrochemical rainwater input into the local groundwater budget during the peak rainfall period (January to March). The October-December (early) period represents a phase between a dusty, dry winter atmosphere and a relatively flushed atmosphere in December, after the first regional rainfall manifests around middle September. Individual early rainfalls contain even higher hydrochemical concentrations than the previous dry period, which subsequently diffuses as the airborne moisture content increases towards the peak rainfall period starting in January. Continuous rainfall event monitoring in the summer semi-arid regions identified short-term wet cycles containing extraordinary high rainfall events, referred to as episodic events. These wet cycles are highly erratic in time and may last from 3 to 8 consecutive days with a recurrence rate of 1 in 5 years. The rainwater hydrochemistry signature differs significantly from the normal rainfall composition and represents a unique opportunity for tracing the infiltrating rainwater For example, chloride concentrations from individual, high rainfall events ( 40 to $150 \mathrm{~mm}$ ) may be as low as $0.4 \mathrm{mg} \cdot \ell^{-1}$, whereas the background value varies around $0.8 \mathrm{mg} \cdot \ell^{-1}$. Environmental chloride represents a conservative tracer for estimating the migration between rainwater and groundwater recharge. The concentration levels are not constant throughout the year and may lead to erroneous assumptions when performing groundwater recharge estimations using accumulated rainwater samples and uncontrolled groundwater sampling techniques.
\end{abstract}

Keywords: monitoring programme, rainfall patterns, rain-week event, rainwater hydrochemical composition, episodic groundwater recharge, water table rebound, rainwater-groundwater interaction

\section{Introduction}

Assessment of groundwater recharge in semi-arid regions requires high-level monitoring of a range of hydrometeorological variables, covering the hydrogeochemistry and rainfall patterns at groundwater recharge terrains (i.e. the fractured, hard rock terrains), as well as the hydrochemistry of the rechargeproducing rainfall surplus reporting at the water table interface. The rising water table response, or rebound, due to effective rainfall-groundwater interaction, presents the physical evidence of groundwater recharge events. These events, when monitored at short-term intervals (hourly measurements), confirm a complex relationship between rainfall patterns (depths and intensities), the flow regime through the unsaturated zone reservoir (UZR), and the hydrochemical evolution from rainwater to groundwater, induced by variable evapotranspiration processes in the UZR.

The hydrological variables collated in this study focus on local, direct groundwater recharge events initiated by local short-term (event-driven) rainfall sequences. This study

\footnotetext{
* To whom all correspondence should be addressed.

용 +2712 663 8121; fax: +2712 326 1488; e-mail: VanWykE2@dwa.gov.za

Received 27 July 2010; accepted in revised form 1 February 2011.
}

covers the monitoring/assessment of seasonal rainfall patterns and rainwater hydrochemical inputs in selected semi-arid regions. A further study will elaborate on the physical interaction between rainfall depth/patterns and groundwater table responses. A third study will exemplify groundwater recharge estimations utilising the chloride mass balance (CMB) application based on a new hydrometeorological and hydrogeochemical monitoring approach.

Winter and summer rainwater hydrochemical compositions deviate significantly because of the respective short and long migration pathways travelled by the airborne moisture loads before actual rainout occurs. Secondary addition of terrigenous salts/dust, intercepted by the atmospheric moisture, introduces measurable changes to the rainwater hydrochemical composition.

Episodic rainfall events occur during short-term atmospheric wet cycles which are characterised by a sequence of rainy days, referenced here as a rain-week condition. This phenomenon consists of a sequence of variable rainfall events taking place over sequential days (i.e. 3 to 8 d), initiated by a regional, wet synoptic system. Characteristically, at least 1 rainfall event in the rain-week is extraordinarily high, $>50$ to $150 \mathrm{~mm}$. Following a rain-week event, local groundwater table hydrographs report extraordinarily high rebounds (several metres) within a few hours/days, indicating a high probability 


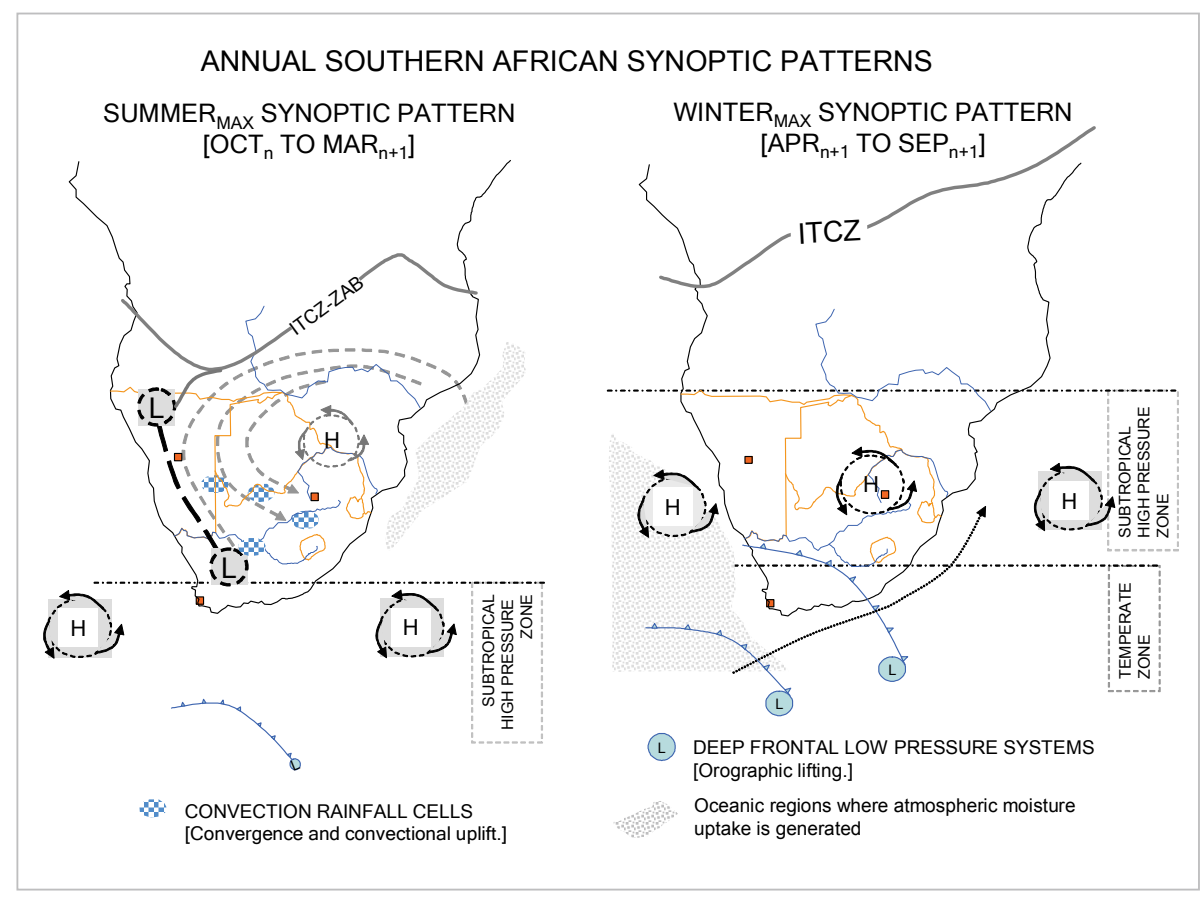

Figure 1

Synoptic patterns over Southern Africa during summer and winter seasons in relation to the generation of airborne moisture and the general migration pathways

of preferential recharge in fractured hard rock terrains.

Fractured hard rock terrains probably represent sporadic, but highly effective, direct recharge zones from which surrounding sub-reservoirs recharge in time. The flow mechanism under these circumstances mimics an L-shaped pathway (Mazor, 1997). The hydrochemical composition of the newly recharged groundwater can only be assessed using special rainwater/groundwater monitoring techniques.

\section{Southern Africa's weather synoptics}

Thomas and Shaw (1991) state that Southern African's unique geomorphology and landmass orientation, relative to the southern hemisphere's atmospheric system, controls weather pattern configurations in the semi-arid region. Southern Africa is situated on the southern tip of an elevated $(\approx 1500 \mathrm{~m}$ a.m.s.1.) wedge-like land mass, delineated by a narrow coastal strip and a prominent elevated escarpment which encircles the interior Karoo/Kalahari Basin. The atmospheric/climatic pattern is altered in such a way that the western side of the Basin tends to be characteristically arid to semi-arid.

The seasonal north-south migration of the Intertropical Convergence Zone (ITCZ), the Subtropical High Pressure Zone (SHPZ) and the Temperate Zone (Antarctic low-pressure system) drives the seasonal rainfall distribution over Southern Africa. The seasonal airborne moisture mass distribution over Southern Africa is therefore highly variable and manifests as prominent summer/winter cycles (Fig. 1).

\section{Generation of atmospheric vapour mass}

Precipitation on Southern African land originates as evaporated water from the surrounding Atlantic and Indian Oceans. Migration from the maritime waters to reach the winter and summer rainfall regions of Southern Africa is unique, thus resulting in a measurable difference between the hydrochemical signatures of rainwater condensates in winter and summer rainfall regions. Post-seasonal mixtures between wet and dry air masses over the interior of Southern Africa alter the air masses' hydrochemical composition even further.

The pathway followed by the evaporated maritime waters, for example, the summer rainfall occurring in the centre of Southern Africa, is several thousand kilometres longer than that for the winter rainfall deriving from the south Atlantic Ocean. Significant changes in the hydrochemical composition, from the original oceanic evaporate/aerosols, occur due to sequential rainouts and introduction of terrigenous dust into the airborne moisture originating from the continent's eroding surface. Winter rainwater precipitating along the western coastal regions of South Africa mimics the maritime waters' high salinity signature that eventually also characterises the local groundwater hydrochemistry.

The differentiation between the summer and winter atmospheric conditions is illustrated in Fig. 1. It illustrates the annual south-north migration of the 3 climate zones and the pathway of synoptic systems during the winter and summer seasons driving various rainfall events over Southern Africa.

\section{Summer rainfall regions}

The most prominent system dominating the Southern African atmosphere in summer time is the ITCZ, positioned across the equator around the mid-summer period ( $\mathrm{Dec}_{\mathrm{n}}$ to $\mathrm{Feb}_{\mathrm{n}+1}$, Fig. 1). This is a complex low-pressure synoptic system enhancing maritime evaporation over the warm, equatorial western Indian Ocean, and probably the eastern Atlantic Ocean, during periods with above-normal seawater temperatures (Summer ${ }_{\text {max }}$ Synoptic Pattern, Fig. 1).

During the peak summer rainfall season ( $\operatorname{Jan}_{n+1}$ to $\operatorname{Mar}_{n+1}$ ), the ITCZ is situated at its most southerly position just north of the Angola-Namibia border, where it links with the southerly Zaire Air Boundary (ZAB). The ZAB acts as a divergence between the ITCZ and a continental thermal low pressure system (the Kalahari Trough), developing around January to March over the western side of Southern Africa due to superheated land surfaces. Moist air migrates along the ITCZ-ZAB from the equatorial Atlantic and Indian Oceans supported by convergent trade winds generated by an interior, moderate high-pressure system oscillating over the north-eastern part 
of the sub-continent (Thomas and Shaw, 1991; Mendelsohn et al., 2002).

The northerly continental anticyclonic system drives both western and eastern airflow components. The upper, easterly moist air masses move into the Kalahari Trough. This oscillating low-pressure system stretches from northern Namibia and passes the southern Cape coastal regions during its maximum domination. Rainstorms are in the form of localised thunderstorm activity instigated by convectional uplift. Regionally, these storm systems are associated in long trough lines, referred to as line storms, and slowly migrate from northwest to southeast over Southern Africa depending on the consistency of the Kalahari low-pressure system (Van Heerden and Hurry, 1992).

During periods with excessive atmospheric moisture loads (an episodic humid event), a band of heavy rain clouds with regional rainfall dominates the summer synoptic picture for several consecutive days, during which rainfall intensities can be significantly high. The magnitude of rainfall intensities during these periods is such that effective groundwater recharge occurs.

\section{Winter rainfall regions}

Towards the winter season, the vertical and horizontal components of the equatorial and southern air circulation system migrate northwards (Winter ${ }_{\text {max }}$ Synoptic Pattern, Fig. 1). Southern Africa's weather pattern is then dominated by the SHPZ. This zone is characterised by 3 prominent high-pressure cells (anticyclones) situated across the sub-continent, i.e. the South Atlantic, the Botswana/Kalahari and the Indian Ocean Anticyclones. The southerly Temperate Zone has shifted substantially north, bringing deep Antarctic air masses to overshoot the southernmost tip of Southern Africa. Westerly winds in this zone carry the cold Antarctic air masses as cold fronts to the western coastal and immediate inland regions of Southern Africa.

Cold, polar air masses may however migrate over large portions of Southern Africa depending on the physical position and strength of the Botswana/Kalahari Anticyclone. Cold fronts are unstable frontal depressions that occasionally mature into deep frontal low pressure systems; their centres commonly pass within $10^{\circ}$ south of the South African coast. Cold frontal bursts over the South Atlantic Ocean generate the winter airborne moisture, in its entirety (Fig. 1). Conventional warm oceanic evaporative principles do not solely account for all airborne moisture generation in the Temperate Zone. Low altitude gale force winds mechanically force maritime moisture directly into these low-lying dry air masses. Once on land, orographic uplift caused by rising land surfaces away from the seaboard, initiates a characteristic $\mathrm{NaCl}$ precipitation.

\section{Rainwater-groundwater monitoring programme}

Investigating hydrochemistry correlations between local rainwater and groundwater requires detailed sampling of both entities, at a time when effective groundwater recharge has occurred after a recharge-producing rainfall surplus event. In addition, medium-term trends and cyclicity in the hydrochemical composition of, specifically, the wet and dry climate periods needs to be recognised. At the local scale, controlled sampling of rainwater, surface water and groundwater is required to ensure the collection of environmentally clean samples at dedicated monitoring terrains.

Addressing the principle of direct-recharge mechanisms in hard rock terrains, dedicated monitoring sites satisfying the concept proposed by De Vries and Simmers (2002) and special rainwater/groundwater sampling equipment is required. Remote areas provide satisfactory conditions for pristine rainwater and groundwater monitoring programmes. These conditions, however, necessitate adequate financial and logistic support to ensure sustainable monitoring for long periods ( $>10$ years). Monitoring teams need regular training and consistency of staff is crucial to sustain the operation and maintenance of these monitoring programmes and networks.

\section{Monitoring terrains}

Specific terrains in the semi-arid region of South Africa have been identified for dedicated rainwater and groundwater quality and quantity monitoring. Six terrains have been designated in the summer rainfall regions of South Africa, characterised by a variety of different local physical conditions, i.e. hard rock terrains, soil/regolith covered plains, local elevated (mountainous) terrains, depression features (i.e. pans) and a semi-desert environment. Four terrains were developed in the winter rainfall, semi-arid region (mainly along the West Coast of South Africa). Data collated from the winter rainfall region could not be applied in-depth for the rainfall-groundwater interaction study due to the high oceanic aerosol depositions in the low-altitude, coastal regions. Two monitoring terrains were designated in urban areas, i.e. at the University of the Western Cape, Bellville and in Lynnwood, Pretoria East. Although violating the requirement for monitoring in pristine conditions, these sites were used to monitor the impact of urban industrial pollution in the local air mass and subsequently the rainwater characteristics.

The monitoring terrains include the following rock formations:

- Palaeo-Mesozoic jointed/weathered Karoo Supergroup sediments (mudstone with sandstone lenses)

- Swazian, deep fractured and weathered Mosita Granite Suite and Randian andesitic Ventersdorp Supergroup lava with banded Kraaipan Formation ironstone windows

- Early Vaalian karstic Chaap Group dolomite and banded ironstones

- Late Vaalian fractured Pretoria Group quartzite

- Mid Mesozoic jointed/weathered Letaba Formation lavas

- Some semi-consolidated Cenozoic seaborne and aeolian Kalahari Group sand deposits

The surface conditions at these selected sites are typical hard rock areas, geologically referenced as windows for the reason that these areas represent preferential, direct recharge terrains. These areas had to be identified by means of regional mapping and assessing soil-cover profiles from bore drilling records.

\section{Rainwater sampling and intervals}

Sampling of rainwater is a rather complex process, especially at remote sites, to ensure pristine conditions. Bulk, accumulated rainwater collection over a period of 3 to 6 months is commonly practised, even internationally, due to the remoteness of these pristine sampling terrains. Individual sampling of single rainfall events can only be achieved by either: having a person dedicated to the monitoring sites, such as occupants of a farm/ nature reserve; or using a dedicated rainwater sampling unit which can sample aliquots from individual rainfall events.

In this study, accumulating logging/sampler units were developed for rainwater quality and quantity monitoring, with 
special controls over local pollution (bird droppings) and, most serious of all, evaporation from the sample container. A special long-term rainwater sampling unit, consisting of an airtight acrylic sampling tube and a stage-height data logger, built into a robust steel housing with a $127 \mathrm{~mm}$ ID funnel, was developed and used on the monitoring sites. The electronic data logger records the incoming rainfall as well as the rainfall depth (mm's), intensity (mm $\mathrm{hr}^{-1}$ ) and duration (HH:mm).

For this study, a specific sampling interval was adopted due to the remoteness of the monitoring terrains. For summer rainfall regions, an early summer interval $\left(\mathrm{Oct}_{\mathrm{n}}\right.$ to $\left.\mathrm{Dec}_{\mathrm{n}}\right)$ and a peak summer interval $\left(\operatorname{Jan}_{n+1}\right.$ to $\left.\operatorname{Mar}_{n+1}\right)$ was followed. For the winter rainfall region, monitoring runs were shifted by approximately 6 months, i.e. early winter $\left(\mathrm{Apr}_{n+1}\right.$ to $\left.\mathrm{Jun}_{\mathrm{n}+1}\right)$ and a peak winter interval $\left(\mathrm{Jul}_{\mathrm{n}+1}\right.$ to $\left.\mathrm{Sep}_{\mathrm{n}+1}\right)$. In some remote regions like the Kalahari only 2 sampling intervals could be established, a summer (wet) interval $\left(\mathrm{Oct}_{\mathrm{n}}\right.$ to $\left.\mathrm{Mar}_{\mathrm{n}+1}\right)$ and a winter (dry) interval $\left(\mathrm{Apr}_{\mathrm{n}+1}\right.$ to $\left.\mathrm{Sep}_{\mathrm{n}+1}\right)$. Dry period sampling in summer $\left(\mathrm{Apr}_{n}\right.$ to $\left.\mathrm{Sep}_{\mathrm{n}}\right)$ and winter $\left(\mathrm{Oct}_{\mathrm{n}}\right.$ to $\left.\mathrm{Mar}_{\mathrm{n}+1}\right)$ rainfall regions was done in order to collect dry atmospheric fallout to estimate the dry $\mathrm{Cl}^{-}$deposition. These values were included with the wet chloride input to calculate total environmental chloride deposition.

\section{Results and discussion}

\section{Hydrochemistry of Southern African rainwater}

\section{Background}

Low-level hydrochemical analyses report significant differences between winter and summer rainwater in the semi-arid environment. In addition, observations recognise sporadic short-term variations related to episodic high rainfall periods during wetter hydrological cycles (HC). It is a well-known fact that Southern Africa experiences wet and dry cycles with total rainfall depths varying up to $100 \%$ and more.

The southern Cape's winter rainfall composition in the low altitude regions contains elevated levels of $\mathrm{Na}^{+}$and $\mathrm{Cl}^{-}$because of high levels of windblown maritime aerosols in the coastal regions. Other constituents are relatively depleted. Compared to the summer rainfall regions, the winter rainwater's $\mathrm{NO}_{3}^{-}$and $\mathrm{SO}_{4}^{2-}$ concentrations are consistently lower, probably an indicator of pristine maritime moisture from the South Atlantic Ocean (Table 1).
The summertime rainwater is influenced by large variations in terrigenous dust generation, a common phenomenon in semiarid regions. In a comprehensive rainwater hydrochemistry study in Central Africa, Galy-Lacaux et al. (2008) analysed 13 different hydrochemical constituents including inorganic and organic elements. The rainwater chemistry in this continental rainfall region changes significantly due to soil dust particles resulting from desertification and intensification of dust emissions and Atlantic dust export.

Terrigenous contributions containing organic aerosols and inorganic inclusions were observed in South Africa during atmospheric related studies (Reason et al., 2006). Site-specific investigations at Amersfoort (eastern Mpumalanga Province) and Louis Trichardt, (northern Limpopo Province) reported rainwater with acidities between 4.91 and 4.35 , and elevated $\mathrm{SO}_{4}^{2-}$ levels as the result of emissions from coal-fired power stations, petrochemical industries and biomass burning from mining and industrial-related activities (Mphepya et al., 2004; Mphepya et al., 2006).

Hydrochemical concentrations in pristine rainwater are relatively low and require specialised laboratory procedures to quantify. The environmental chloride concentrations in many cases were at detection level of $0.1 \mathrm{mg} \cdot \ell^{-1}$. For this study only 5 macro-chemistry constituents in rainwater were analysed at low level detection, i.e. $\mathrm{Cl}^{-}, \mathrm{NO}_{3}^{-}, \mathrm{SO}_{4}^{2-}$ and $\mathrm{PO}_{4}^{-}$, by anion chromatography.

\section{Rainwater quality variation due to terrigenous dust and local pollution}

Precipitation chemistry research in a remote dry savanna site in Niger suggests that dust particles coming from desert and semiarid regions may substantially alter the hydrochemical composition of rainwater (Galy-Lacaux et al., 2008). This research team reports that ionic concentrations of rainwater studied in the Sahelian region show elevated levels of dissolved calcium and carbonates (calcite). Approximately $40 \%$ of the total ionic charge of the sampled rainwater has a $\mathrm{CaHCO}_{3}$ composition, which annihilates the initial saline maritime signature.

The impact of burnt biomass, producing sulphate particles, in the summer rainfall regions of South Africa was reported (Reason et al., 2006). In this study, rainwater sampled as far west as Beaufort West and as far north as the Kalahari region (Van Zylsrus) reported occasional $\mathrm{SO}_{4}^{2-}$ spikes as high as 10 to $15 \mathrm{mg} \cdot \ell^{-1}$. The rainwater collected from sampling units close

\begin{tabular}{|c|c|c|c|c|c|}
\hline \multicolumn{6}{|c|}{$\begin{array}{c}\text { Table } 1 \\
\text { Comparison of rainwater hydrochemical composition (in } \mathrm{mg} \cdot \mathrm{e}^{-1} \text { ) between a collection } \\
\text { of ecosystems in Africa based on a study of semi-arid regions in the Sahel, Niger and } \\
\text { South Africa (modified after Galy-Lacaux et al., 2008). }\end{array}$} \\
\hline Ecosystem & Location & $\mathrm{Na}^{+}$ & $\mathrm{Cl}^{-}$ & $\mathrm{NO}_{3}$ & $\mathrm{SO}_{4}$ \\
\hline Dry Savanna & Niger & 0.18 & 0.26 & 0.19 & 0.41 \\
\hline Dry Savanna & Niger, Sahel & 0.20 & 0.31 & 0.18 & 0.41 \\
\hline \multirow[t]{2}{*}{ Semi-arid Savanna } & South Africa ${ }^{1}$ & 0.21 & 0.35 & 0.39 & 2.84 \\
\hline & South Africa $^{2}$ & 0.21 & 0.35 & 0.12 & 0.70 \\
\hline Wet Savanna & Côte d'Ivore & 0.14 & 0.25 & 0.12 & 0.31 \\
\hline Forest & Cameroon & 0.09 & 0.15 & 0.11 & 0.25 \\
\hline Semi-arid (Summer) & South Africa ${ }^{3}$ & 0.3 & 0.44 & 0.66 & 1.06 \\
\hline Semi-arid (Winter) & South Africa ${ }^{4}$ & 1.9 & 2.67 & 0.18 & 0.07 \\
\hline \multicolumn{6}{|c|}{$\begin{array}{l}\text { I Amersfoort, South Africa (Mphepya, } 2005 \text { in Galy-Lacaux et al., 2008). } \\
{ }^{2} \text { Louis Trichardt, South Africa (Mphepya, } 2005 \text { in Galy-Lacaux et al., 2008). } \\
{ }^{3} \text { This study-Jan-Mar for Beaufort West, Stella, Kuruman, Alldays, and Van Zylsrus. } \\
{ }^{4} \text { This study-Jun-Aug for Cape Town, Langebaan Road, Sandveld Area and Oudtshoorn. }\end{array}$} \\
\hline
\end{tabular}




\begin{tabular}{|c|c|c|c|c|c|}
\hline \multicolumn{6}{|c|}{$\begin{array}{c}\text { Table } 2 \\
\begin{array}{c}\text { Rainwater hydrochemistry }\left(\mathrm{mg} \cdot \ell^{-1}\right) \text { as impacted by animal droppings and dry season } \\
\text { compositions in summer and winter semi-arid regions. }\end{array}\end{array}$} \\
\hline Constituent & $\mathrm{Na}$ & $\mathrm{Cl}$ & $\mathrm{NO}_{3}$ & $\mathrm{SO}_{4}$ & $\mathrm{PO}_{4}$ \\
\hline Severe bird droppings (owls and hawks) & 8.1 & 13.6 & 61.0 & 62.7 & 1.21 \\
\hline Occasional bird droppings & 0.6 & 1.8 & 17.3 & 1.2 & 0.13 \\
\hline Summer dry (Apr-Sep) composition & 0.5 & 1.0 & 0.48 & 2.11 & $<0.05$ \\
\hline Winter dry (Oct-Mar) composition & 1.4 & 6.8 & 0.18 & 0.32 & $<0.05$ \\
\hline
\end{tabular}

Table 3

Summer rainfall anion concentrations $\left[\mathrm{mg} \cdot \ell^{-1}\right]$ in semi-arid regions of South Africa for the 3-tier intervals (early | peak | dry) over the HC and correlated with some local land use activities. Values are harmonic means of a population of selected analyses.

\begin{tabular}{|c|c|c|c|c|c|c|c|c|c|c|c|c|c|c|c|c|c|c|}
\hline \multirow{2}{*}{$\begin{array}{l}\text { Attribute } \\
\text { Anions: }\end{array}$} & \multicolumn{3}{|c|}{ Karoo Region ${ }^{1}$} & \multicolumn{3}{|c|}{ Savanna Region² } & \multicolumn{3}{|c|}{ Ghaap Plateau $^{3}$} & \multicolumn{3}{|c|}{ Urban Highveld $^{4}$} & \multicolumn{3}{|c|}{$\begin{array}{c}\text { Bushveld } \\
\text { Region }^{5}\end{array}$} & \multicolumn{3}{|c|}{$\begin{array}{c}\text { Kalahari } \\
\text { Sandveld }^{6}\end{array}$} \\
\hline & \multicolumn{18}{|c|}{$\mathrm{mg} \cdot \mathrm{e}^{-1}$} \\
\hline $\mathrm{Cl}^{-}$ & 0.8 & 0.7 & 1.3 & 0.9 & 0.8 & 1.0 & 0.7 & 0.4 & 1.0 & 0.6 & 0.3 & 1.0 & 1.0 & 0.7 & 2.0 & 0.7 & 0.3 & 0.8 \\
\hline $\mathrm{SO}_{4}^{2-}$ & 0.1 & 0.8 & 1.1 & 3.6 & 2.7 & 1.1 & 1.3 & 1.0 & 1.5 & 1.6 & 1.4 & 5.0 & 0.1 & 2.2 & 4.1 & 2.4 & 0.6 & 1.6 \\
\hline $\mathrm{NO}_{3}^{-}$ & 0.9 & 0.2 & 1.4 & 1.1 & 0.7 & $\mathrm{j}$ & 0.1 & $\mathrm{j}$ & 1.6 & 1.4 & 0.4 & 0.5 & 0.1 & 0.1 & 0.1 & 0.9 & 0.3 & 1.6 \\
\hline
\end{tabular}

${ }^{1}$ Beaufort West area (northeast), towards the Nuweveld Escarpment, Western Cape - wildlife reserve

${ }^{2}$ Stella area, Vryburg District (south), Northern Cape - stock farming and dryland irrigation

${ }^{3}$ Catchment of the Kuruman A-Eye at Kuruman (south), Northern Cape-wildlife reserve

${ }^{4}$ Pretoria East (Lynnwood-Garsfontein), Gauteng (semi-humid region) - urban residential

${ }_{5}^{5}$ Taaiboschgroet area in the Alldays District (southwest), Limpopo - wildlife reserve

${ }^{6}$ Van Zylsrus area (west), Gordonia District, Northern Cape-wildlife reserve

$j$ Not detected, concentration level probably $<0.05 \mathrm{mg} \cdot \ell^{-1}$

to mining/industrial activities in the Free State Province, for example, reported elevated levels of $\mathrm{SO}_{4}^{2-}\left(\approx 25 \mathrm{mg} \cdot \ell^{-1}\right)$ and $\mathrm{NO}_{3}^{-}$ $\left(\approx 44 \mathrm{mg} \cdot \ell^{-1}\right)$, probably as a result of local coal-burning furnaces, biomass incinerations and regional atmospheric circulation from heavily polluted air masses further east (Highveld Region).

Local addition of biomass (mainly bird/animal droppings) to rainwater samplers alters the chloride concentration levels to such an extent that the hydrochemical composition becomes meaningless. It was therefore crucial to include special indicators to identify the presence of unwanted additions such as bird droppings. Table 2 illustrates the impact of bird droppings. In these cases, the whole hydrochemical package is enriched; thus useless for any application.

Phosphate is probably the best indicator of organic pollution in rainwater samples. High phosphate values $\left(>1.00 \mathrm{mg} \cdot \ell^{-1}\right.$ for severe affected and $\approx 0.15 \mathrm{mg} \cdot \ell^{-1}$ for occasional affected) correlate with elevated values for $\mathrm{Cl}^{-}, \mathrm{NO}_{3}^{-}$and $\mathrm{SO}_{4}^{2-}$. However, $\mathrm{PO}_{4}^{-}$-concentrations in rainwater composition in this study were frequently reported as undetected $\left(<0.05 \mathrm{mg} \cdot \ell^{-1}\right)$; thus the rainwater sampling methodology applied in fact captured exceptionally clean meteoric water (Table 2). The data also illustrate the dry atmospheric composition, which highlights the differences between the winter and summer concentrations; especially the high levels of oceanic aerosols (i.e. $\mathrm{NaCl}$ ).

\section{Summer rainwater hydrochemical properties}

The origin of summer rainstorms in Southern Africa, as described above, is predominantly western Indian and occasionally eastern Atlantic Ocean evaporated maritime water. It is expected that a comprehensive dose of terrigenous dust is introduced into the atmospheric air column during its migration over the African sub-continent (Rozanski et al., 1996; Rouault et al., 2003; Reason et al., 2006). The hydrochemical composition is further altered by consecutive moisture loss (via continental rainouts) and addition (via continental evapotranspiration) cycles in the tropic/sub-tropic forest regions, which also alters the rainwater's isotopic composition (Joseph et al., 1992).

The summer rainfall period in semi-arid Southern Africa runs from Oct $_{\mathrm{n}}$ to $\mathrm{Mar}_{\mathrm{n}+1}$. Rainfall hyetographs from monitoring sites used in this study highlight the months of January, February and March as peak rainfall periods, when $\pm 80 \%$ of the total annual precipitation occurs. Three distinct intervals have been identified and fit roughly into the official Oct ${ }_{n}$ to Sep $_{n+1}$ HC for Southern Africa. They are:

- An early period which runs from mid-Sep to Dec $\mathrm{n}_{\mathrm{n}}$, initially consisting of a few isolated rainfall events some days/ weeks apart, followed by some heavier falls in late $\mathrm{Dec}_{\mathrm{n}}$

- A peak period which runs from Jan ${ }_{n+1}$ to mid-Apr ${ }_{n+1}$ consisting of recurring rainfall events, and may include a rain-week scenario with an occasional extraordinarily high (40-150 $\mathrm{mm}$ ) rainfall event

- The typical semi-arid dry period, which runs from midApr $_{n+1}$ to mid-Sep ${ }_{n+1}$. Although this period is classified as dry, some sporadic low $(<15 \mathrm{~mm})$ rainfall events may occur.

Analytical results for the 3-tier interval period are reported in Table 3. With reference to the continental, cyclic climate pattern in Southern Africa during summertime, the $\mathrm{HC}$ can be characterised with:

- An initial, but effective flushing of a dusty atmosphere during the early wet period from $\mathrm{Oct}_{n}$ to $\mathrm{Dec}_{n}$

- An almost dust-free atmosphere with pristine rainwater between $\operatorname{Jan}_{n+1}$ and $\mathrm{Mar}_{\mathrm{n}+1}$ (bolded figures)

- Followed a gradual build-up of dusty, dry atmospheric conditions with irregular terrigenous dust additions between $\operatorname{Apr}_{n+1}$ and $\operatorname{Sep}_{n+1}$ 


\begin{tabular}{|c|c|c|c|c|c|c|c|c|c|c|c|c|}
\hline \multicolumn{13}{|c|}{$\begin{array}{c}\text { Table } 4 \\
\text { Winter rainfall anion concentrations in semi-arid regions of South Africa for the 3-tier } \\
\text { intervals (early | peak | dry) over the HC correlated with local land use activities. } \\
\text { Values are harmonic means of a population of selected analyses. }\end{array}$} \\
\hline Attribute & \multicolumn{3}{|c|}{ West Coast Sandveld ${ }^{1}$} & \multicolumn{3}{|c|}{ Cape Peninsula ${ }^{2}$} & \multicolumn{3}{|c|}{ West Coast Langebaan $^{3}$} & \multicolumn{3}{|c|}{ Klein Karoo Region ${ }^{4}$} \\
\hline Anions: & \multicolumn{12}{|c|}{$\mathrm{mg} \cdot \mathrm{e}^{-1}$} \\
\hline $\mathrm{Cl}^{-}$ & 2.4 & 2.0 & 4.6 & 13.0 & 5.1 & 8.9 & 9.7 & 6.0 & 8.6 & 1.9 & 1.6 & 6.8 \\
\hline $\mathrm{SO}_{4}^{2-}$ & 0.2 & $\mathrm{j}$ & 0.2 & 10.6 & 8.8 & 8.3 & 3.6 & 0.8 & 0.2 & 1.9 & 0.4 & 0.5 \\
\hline $\mathrm{NO}_{3}^{-}$ & $\mathrm{j}$ & 0.1 & $\mathrm{j}$ & 0.1 & 2.7 & $\mathrm{j}$ & 0.3 & 0.2 & 0.6 & $\mathrm{j}$ & 0.2 & $\mathrm{j}$ \\
\hline \multicolumn{13}{|c|}{$\begin{array}{l}{ }^{1} \text { Klein Klipheuwel, Elands Bay Area - low to medium }(350 \mathrm{~m} \text { a.m.s.l.) altitudes and typical rural. } \\
{ }^{2} \text { Univ, Western Cape, Bellville Area (not a semi-arid region, but included to show local atmospheric pollution in urban/industrial areas) - } \\
\text { urban industrial } \\
{ }^{3} \text { Langebaan Road, Vredenburg District - dryland irrigation and stock farming } \\
{ }^{4} \text { Vermaaks River Valley, District Oudtshoorn }- \text { wildlife reserve } \\
\text { j Not detected, concentration level probably }<0.05 \mathrm{mg} \cdot \ell^{-1}\end{array}$} \\
\hline
\end{tabular}

Average $\mathrm{Cl}^{-}$-concentrations (harmonic means) for the summer rainfall in semi-arid regions of Southern Africa are:

- $0.8 \mathrm{mg} \cdot \ell^{-1}$ for the early period $\left(\mathrm{Sep}_{\mathrm{n}}\right.$ to $\left.\mathrm{Dec}_{\mathrm{n}}\right)$ representing $30 \%$ of rainfall depth

- $0.4 \mathrm{mg} \cdot \ell^{-1}$ for the peak period ( $\operatorname{Jan}_{\mathrm{n}+1}$ to $\mathrm{Mar}_{\mathrm{n}+1}$ ) representing $65 \%$ of rainfall depth

- $1.0 \mathrm{mg} \cdot \ell^{-1}$ for the dry period $\left(\mathrm{Apr}_{\mathrm{n}+1}\right.$ to $\left.\mathrm{Sep}_{\mathrm{n}+1}\right)$ representing $5 \%$ of rainfall depth

The standard deviations for the above-mentioned intervals are $<0.1,<0.1$ and $\approx 0.2$ out of 71,89 and 66 analyses, respectively.

To conclude, the summertime hydrochemical composition indicates strong seasonal variations. The variation between peak period values of $0.4 \mathrm{mg} \cdot \ell^{-1}$ and the dry and early wet period values of 0.8 to $1.0 \mathrm{mg} \cdot \ell^{-1}$ is to be noted when applying environmental chloride for rainwater-groundwater interaction estimations. Estimates of separate recharge pulses over shorter intervals in the $\mathrm{HC}$ instead of annual averages may provide more realistic recharge values.

\section{Winter rainwater hydrochemical properties}

The winter rainwater hydrochemical character is significantly different from the summer rainwater composition, due to the rainwater having been generated over a stormy southern Atlantic Ocean, and a rather short migration path from seaboard to the final rainout terrain on land (less than $200 \mathrm{~km}$ versus several thousand kilometres for the summer airborne moisture column).

The variation in winter rainwater hydrochemistry over the $\mathrm{HC}$ follows almost the same 3-tier interval pattern as for the summer rainfall region, although shifted by 6 months (Table 4).

Similar to summer rainwater, winter rainwater reports lighter hydrochemical concentrations during the peak rainfall period $\left(\mathrm{Jul}_{\mathrm{n}}\right.$ to $\mathrm{Sep}_{\mathrm{n}}$ ). However, the variation over the $\mathrm{HC}$ is large (Table 4; Fig. 2). Long-term minimum-maximum $\mathrm{Cl}^{-}$ ranges, for example, in the Cape Peninsula area (University of the Western Cape) vary between 3.5 and $16.8 \mathrm{mg} \cdot \ell^{-1}$, and in the Langebaan Road area further north, vary between 5 and $10 \mathrm{mg} \cdot \ell^{-1}$. Further inland from the West Coast seaboard, with increasing altitude, $\mathrm{Cl}^{-}$values varies between $1.5 \mathrm{mg} \cdot \ell^{-1}$ and $7.9 \mathrm{mg} \cdot \ell^{-1}$. In the Little Karoo area, (Vermaaks River, Dysselsdorp) at a much higher altitude, Clvalues vary between 1.0 and $5.3 \mathrm{mg} \cdot \ell^{-1}$. The same maritime impact on the local rainwater hydrochemistry occurs along the Kwazulu-Natal northern coastal regions (Fig. 2) This rainfall occurs during the Southern African summer season, generated by a warm offshore Agulhas Current (Rouault et al., 2001).

Harmonic mean $\mathrm{Cl}^{-}$concentrations for the Western Cape's winter rainwater, as observed between 2003 and 2006, are:

- $\quad 3.6 \mathrm{mg} \cdot \ell^{-1}$ for the early period $\left(\mathrm{Apr}_{\mathrm{n}}\right.$ to $\left.\mathrm{Jun}_{\mathrm{n}}\right)$, representing $30 \%$ of total rainfall depth

- $2.8 \mathrm{mg} \cdot \ell^{-1}$ for the peak period $\left(\mathrm{Jul}_{\mathrm{n}}\right.$ to $\mathrm{Sep}_{\mathrm{n}}$ ), representing $60 \%$ of total rainfall depth

- $6.8 \mathrm{mg} \cdot \ell^{-1}$ for the dry period $\left(\mathrm{Oct}_{\mathrm{n}}\right.$ to $\left.\mathrm{Mar}_{\mathrm{n}+1}\right)$, representing $10 \%$ of rainfall depth

The standard deviation for each of the above-mentioned intervals is $0.4,0.4$ and 0.8 from 23,24 and 30 analyses, respectively.

\section{Regional distribution of environmental chloride over Southern Africa}

The regional rainwater hydrochemistry over Southern Africa varies from coastal to inland regions due to the diverse nature of the generation of atmospheric moisture and rainfall patterns over Southern Africa. Figure 2 illustrates the actual 3-tier $\mathrm{Cl}^{-}$concentrations observed in 19 national rainfall monitoring stations over South Africa. It highlights a significant difference between the coastal and interior $\mathrm{Cl}^{-}$concentration levels and seasonal variation due to wet/dry $\mathrm{Cl}^{-}$deposition. These values represent harmonic mean values monitored over 3 summer and winter intervals (early, peak and dry) for a period of 7 years.

The data disclose that the summertime rainwater input to the interior regions of Southern Africa is hydrochemically lighter than the rainwater in the coastal regions. The summer peak period's chloride concentrations, for example, fall between 0.3 and $0.5 \mathrm{mg} \cdot \ell^{-1}-\mathrm{Cl}^{-}$. Some spatial differences, especially for the dry period, occur, and could be related to local climatic conditions impacting on the dry to early period's chloride deposition, i.e. the dryland farming area (Petrusburg) between Bloemfontein and Kimberley (Fig. 2) (Van Tonder and Bean, 2003). Rainwater $\mathrm{Cl}^{-}$values determined for the first few rainfall events of the summer season (early period) are almost of the same order as the previous dry period's input. The early period values reported in Fig. 2 are lower due to heavier rainfall input towards the end of the early period (c. end-December) which to some extent dilutes the bulk sample $\left( \pm 0.8 \mathrm{mg} \cdot \ell^{-1}-\mathrm{Cl}^{-}\right)$.

Coastal regions, on the contrary, report the presence of oceanic aerosols that manifest significantly in the environmental chloride concentration levels as part of the $\mathrm{NaCl}$ input, as indicated in Fig. 2. However, significant depletion from the shoreline to the interior occurs in the West Coast Region and at 
Collected over a three tier interval as follows:

Early ( S: Oct $\left.\mathrm{n}_{\mathrm{n}}-\mathrm{Dec}_{\mathrm{n}}\right) ;\left(\mathrm{W}: \mathrm{Apr}_{\mathrm{n}+1}-\mathrm{Jun}_{\mathrm{n}+1}\right)$

Peak ( S:Jan $\left.{ }_{n+1}-\operatorname{Mar}_{n+1}\right) ;\left(\right.$ W:Jul $\left.{ }_{n+1}-\operatorname{Sep}_{n+1}\right)$

Figure 2

Rainwater

chloride

concentrations

$\left(m g \cdot \ell^{-1}\right)$ in South

Africa monitored

between 2003

and 2009
Dry ( S:Apr ${ }_{n+1}-$ Sep $\left._{n+1}\right) ;\left(\right.$ W:Oct $\left.n-M_{n+1}\right)$

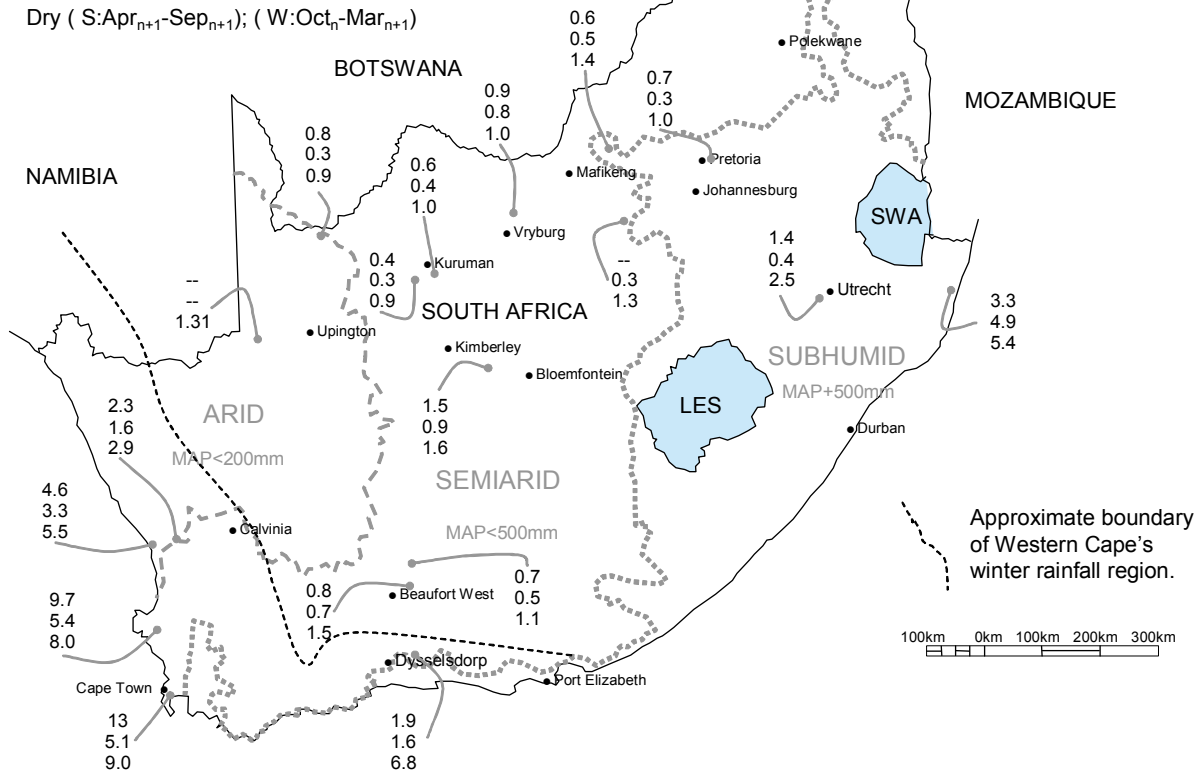

Dysselsdorp (Southern Cape), probably due to intensified orographic uplift-rainout effects towards higher altitudes (Fig. 2).

\section{Dry chloride deposition in semi-arid regions}

The chloride mass balance (CMB) application is one of the methodologies to quantify groundwater recharge estimates. Determining the ratio of average (harmonic mean) $\mathrm{Cl}^{-}$content in rainwater to that in groundwater, estimation of evapotranspiration and groundwater recharge rates is quite straightforward, given good long-term hydrometeorological data.

The total chloride input from the atmospheric outfall needs to be estimated by means of wet and dry atmospheric fallout sampling. Using the same rainfall-logging units used for the wet period sampling, capturing the dry $\mathrm{Cl}^{-}$input was possible in the same manner as studies done in Botswana (Gieske, 1992). It is remarkable to highlight the concentration of airborne dust particles sampled during dry periods (i.e. summertime from $\mathrm{Apr}_{\mathrm{n}}$ to Sept $\mathrm{n}_{\mathrm{n}}$ and wintertime from Oct ${ }_{\mathrm{n}}$ to $\left.A r_{n+1}\right)$, even in pristine areas, which is an indication of the level of build-up of atmospheric dust and foreign substances in Southern Africa's atmosphere.

Dry chloride values have been reported to be approximately $400 \mathrm{mg} \cdot \mathrm{m}^{2} \cdot \mathrm{yr}^{-1}$ for Southern Africa, from studies by Eriksson (1960) and Gieske, (1992) as far back as 1984. Total seasonal chloride deposition values calculated for the Kuruman, Beaufort West, Vryburg and Pretoria East monitoring sites, were 260 $\mathrm{mg} \cdot \mathrm{m}^{2} \cdot \mathrm{yr}^{-1}$, of which roughly $30 \%$ or $80 \mathrm{mg} \cdot \mathrm{m}^{2} \cdot \mathrm{yr}^{-1}$ occurs as atmospheric outfall during the dry winter months. Gieske's (1992) estimation for the dry chloride content in the total deposition for Botswana (1992) was around $20 \%$ of the total deposition.

\section{Extraordinary rainfall events}

Extraordinary rainfall events in semi-arid regions represent episodic occurrences. The rainfall depths are commonly 1.5 to 2 times the recorded long-term, average monthly rainfall depths. Episodic rainfall events were noted during, and are characteristic of, the rain-week periods. Some rainfall events during a rain-week are extraordinarily intensive (i.e. $200 \mathrm{~mm}$ in a few hours) initiating a high incidence of depression storage at ground level.

Episodic rainfall events report significantly different rainwater hydrochemical compositions and should bear a traceable recharged component when a recharge-producing rainfall surplus condition occurs. For example, correlations between these episodic rain events and rainwater with extreme low chloride content have been observed during individual, rain events over a rain-week period. Individual rainwater aliquots collected during an episodic rain-week scenario ( $87 \mathrm{~mm}$ over $2 \mathrm{~d}$ and $1 \mathrm{~h}$ ) reported a weighted mean $\mathrm{Cl}^{-}$concentration in the order of 0.3 $\mathrm{mg} \cdot \ell^{-1}$. Some of the individual $\mathrm{Cl}^{-}$concentrations for high rainfall depths $(>50 \mathrm{~mm})$, however, were at the laboratory detection level, i.e. $0.1 \mathrm{mg} \cdot \ell^{-1}$.

\section{Rainwater-groundwater interaction}

The interaction between high rainfall events (in particular the characteristic episodic $>40 \mathrm{~mm}$ rainfall depths) and the local groundwater table response is quite significant in the semi-arid regions. The monitoring programme enabled time-series presentations of local rainfall depths and water table responses in the form of hyetograph-hydrographs diagrams. These diagrams illustrate the complexities around ground surface and geophysical conditions of the unsaturated zone reservoir (UZR) that controls the hydrochemical and flow dynamics of the recharging water (Van Tonder and Bean, 2003).

\section{Conclusions and recommendations}

Rainfall patterns in the semi-arid regions of Southern Africa fluctuate because of the north-south oscillations of the southern 
hemisphere's atmospheric zones. Dedicated observations of long-term rainfall patterns show that roughly 1 in 5 Southern African HCs contain a sequence of high-input rainfall events spaced over a high intensity rain-week period, which may total 250 to $300 \mathrm{~mm}$. Advanced sampling of rainwater under these conditions reports extremely low hydrochemical concentrations. Individual samples from various rainfall depths report $\mathrm{Cl}^{-}$concentration levels between 0.1 and $0.5 \mathrm{mg} \cdot \ell^{-1}$.

Annual rainwater hydrochemistry varies considerably, especially in the Southern African semi-arid climate, given the diverse migration pathway which the airborne moisture follows from the Indian (summer) and Atlantic (winter) maritime source areas.

Summertime rainwater composition is specifically altered by the addition of terrigenous dust originating from land surfaces as the result of natural and anthropogenic processes occurring at the ground surface. Dry chloride outfall in the summer rainfall region is rather complex and dedicated monitoring is required to differentiate between dry, early and peak period inputs, especially in areas where intensive dryland farming is practiced i.e. in the semi-arid provinces (Northwest, Free State, Gauteng and Limpopo Provinces). In addition, natural dusty conditions, especially in the Karoo semi-arid environment, apparently affect the dry chloride values as well. Dry $\mathrm{Cl}^{-}$content is in the order of $80 \mathrm{mg} \cdot \mathrm{m}^{2} \cdot \mathrm{yr}^{-1}$ and represents roughly $30 \%$ of the total atmospheric deposition.

Winter rainfall composition, on the contrary, retains most of its initial $\mathrm{NaCl}$ maritime composition and imposes a basic saline aerosol signature on the rainwater composition in coastal and immediate inland areas. This signature is persuasively imprinted on the local groundwater environment, i.e. low mineralised water, $\left(<50 \mathrm{mg} \cdot \ell^{-1}\right)$ but with a prominent $\mathrm{NaCl}$ signature.

Rainwater $\mathrm{Cl}^{-}$concentrations in the coastal regions are almost an order of magnitude higher than that for the summer rainfall regions. Application of environmental $\mathrm{Cl}^{-}$as a hydrological tracer in the coastal regions should therefore be approached carefully. Unless a comprehensive, long-term record of the rainwater/groundwater hydrogeochemistry composition is available, the CMB should not, primarily, be considered.

Application of the Chloride Mass Balance methodology in Southern African geo-environments should be applied with great care and consideration. Isolated and accumulated collection of rainwater/groundwater samples is not advisable as the variation in rainwater and groundwater chloride content in time and space could be significantly high $(>50 \%)$, as was observed during this study.

\section{Acknowledgements}

The information presented in this paper forms part of a wide range of hydrological monitoring programmes managed by the South African Department of Water Affairs (DWA). The rainwater-groundwater monitoring programme is managed by the DWA Directorate Hydrological Services and the DWA Regional Offices throughout South Africa. We are grateful to the many departmental officials who have contributed to the authorisation, advice on, and physical establishment of the network, as well as timeous operation and maintenance thereof. Special appreciation is expressed to Dr JC Vogel, (former head of the QUADRU isotope facilities at CSIR, Pretoria) for allowing us to use his private borehole and lawn area for one of the urban rainwater and groundwater monitoring terrains, i.e. the Pretoria East Monitoring Site.

\section{References}

DE VRIES JJ and SIMMERS I (2002) Groundwater recharge: an overview of processes and challenges. Hydrol. J. 10 5-17.

ERIKSSON E (1960) The yearly circulation of chloride and sulphur in nature; meteorological, geochemical and pedological implications. Part II Tellus 12 (1) 63-109.

GALY-LACAUX C, LAOUALI D, DESCROIX L, GORBRON N and LIOUSSE C (2008) Long term precipitation and wet deposition in a remote dry savanna site in Africa (Niger). Atmos. Chem. Phys. Discuss. 8 5761-5812.

GIESKE A (1992) Dynamics of Groundwater Recharge. A Case Study in Semi-Arid Eastern Botswana. Drukkerij Febodruk BV, Enschede, The Netherlands. 289 pp.

JOSEPH A, FRANGI JP and ARANYOSSY JF (1992) Isotope charactersitics of meteoric water and groundwater in the Sahelo-Sudanese Zone. J. Geophys. Res. 97 (D7) 7543-7551.

MAZOR E (1997) Chemical and Isotopic Groundwater Hydrology. The Applied Approach ( $2^{\text {nd }}$ edn.). Marcel Dekker Inc., New York. 413 pp.

MENDELSOHN J, JARVIS J, ROBERTS C and ROBERTSON T (2002) Atlas of Namibia, A Portrait of the Land and its People. Ministry of Environment and Tourism. Namibia. New Africa Books, Cape Town. 199 pp.

MPHEPYA JN, PIENAAR JJ, GALY-LACAUX C, HELD G and TURNER CR (2004) Precipitation chemistry in semi-arid areas of Southern Africa: A case study of a rural and an industrial site. J. Atmos. Chem. 47 1-24.

MPHEPYA JN, GALY-LACAUX C, LACAUX JP, HELD G and PIENAAR JJ (2006) Precipitation chemistry and wet deposition in Kruger National Park, South Africa. J. Atmos. Chem. 53 169-183.

REASON CJC, ENGELBRECHT F, LANDMAN WA, LUTJEHARMS JRE, PIKETH S, RAUTENBACH C De W and HEWITSON BC (2006) A review of South African research in atmospheric science and physical oceanography during 2005-2006. S. Afr. J. Sci. 102 35-45.

ROUAULT M, JOBARD J, WHITE SA and LUTJEHARMS JRE (2001) Studying rainfall events over South Africa and adjacent oceans using the TRMM satellite. S. Afr. J. Sci. 97 455-460.

ROUAULT M, FLORENCHIE P, FAUCHERAU N and REASON CJC (2003) South East tropical Atlantic warm events and southern African rainfall. Geophys. Res. Lett. 30 (5) CLI 9-1 - CLI 9-4.

ROZANSKI K, ARAGAUS-ARAGAUS L and GONFIANTINI R (1996) Isotope patterns of precipitation in the East African Region. In: Johnson TC and Odada EO (eds.) The Limnology, Climatology and Paleonclimatology of the East African Lakes. 79-93.

THOMAS DSG and SHAW PA (1991) The Kalahari Environment. Cambridge University Press, Cambridge. 284 pp.

VAN HEERDEN J and HURRY L (1992) Southern Africa's Weather Patterns. An Introductory Guide, Acacia, Pretoria. 95 pp.

VAN TONDER GJ and BEAN JA (2003) Challenges in estimating groundwater recharge. In: Xu Y and Beekman HE (eds.) Groundwater Recharge Estimation in Southern Africa, UNESCO IHP Series 64. UNESCO, Paris. 207 pp. 